\title{
Effects of feed rations containing egg powder in different proportions on growth performance, feed utilization, body composition and survival rate of rainbow trout (Oncorhynchus mykiss Walbaum, 1792) fry
}

\section{Farklı oranlardla yumurta tozu içeren yem rasyonlarının yavru gökkuşağı alabalığının (Oncorhynchus mykiss walbaum, 1792) büyüme performansı, yem kullanımı, vücut kompozisyonu ve yaşam oranına etkileri}

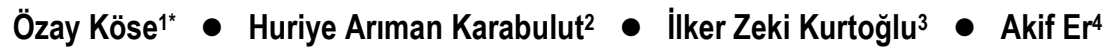 \\ ${ }^{1}$ Recep Tayyip Erdogan University, Faculty of Fisheries and Aquaculture, Rize, 53100, Turkey \\ ${ }^{2}$ Recep Tayyip Erdogan University, Faculty of Fisheries and Aquaculture, Rize, 53100, Turkey \\ ${ }^{3}$ Recep Tayyip Erdogan University, Faculty of Fisheries and Aquaculture, Rize, 53100, Turkey \\ ${ }^{4}$ Recep Tayyip Erdogan University, Faculty of Fisheries and Aquaculture, Rize, 53100, Turkey \\ (i) $h$ ttps://orcid.org/0000-0002-3565-160X \\ (D) $h$ ttps://orcid.org/0000-0002-9171-2024 \\ (D) $h$ ttps://orcid.org/0000-0002-4214-7997 \\ (D) https://orcid.org/0000-0002-0052-5590
}

*Corresponding author: ozay.kose@erdogan.edu.tr_Received date: 19.02.2020

Accepted date: 09.11.2020

\section{How to cite this paper:}

Köse, Ö., Karabulut Arıman.H., Kurtoğlu, İ.Z. \& Er, A. (2021). Effects of feed rations containing egg powder in different proportions on growth performance, feed utilization, body composition, and survival rate of rainbow trout (Oncorhynchus mykiss Walbaum, 1792) fry. Ege Journal of Fisheries and Aquatic Sciences, 38(1), 69-78. DOI: 10.12714/egejfas.38.1.08

Abstract: This study aims to determine the appropriate egg powder ratio that can be substituted into the fish meal to close the protein deficit without adversely affecting the development performance of rainbow trout fry (Oncorhynchus mykiss) $(0.38 \pm 0.01 \mathrm{~g}$ and $3.55 \pm 0.05 \mathrm{~cm})$. Also, the effects of egg powder used as a protein source on rainbow trout feed on growth performance, feed utilization, body composition, and survival rates were investigated. The egg powder ratio in the ration of the groups were arranged to be $0 \%$ (Control), 25\% (E-25), 50\% (E-50), 75\% (E-75), and 100\% (E-100) of the amount of protein obtained from fish meal. To evaluate their growth performance, fish were fed for 90 days between March and May, and additional feeding was given for 17 days for the challenge test. As a result of the study, when the more than $25 \%$ egg powder was added to the ration, the final body weight (FBW), weight gain (WG), weight gain rate (WGR), specific growth rate (SGR), feed intake (FI), and protein efficiency ratio (PER) had a statistically significant difference among the groups $(p<0.05)$. It was determined that the difference between groups was insignificant in terms of condition factor $(C F)$, and the addition of more than $25 \%$ egg powder to the ration increased the feed conversion ratio (FCR) statistically and significantly ( $p<0.05$ ). As a result of the challenge test carried out with two different fish pathogens (Lactococcus garvieae and Yersinia ruckeri), it was determined that the addition of egg powder decreased the survival rate in all groups compared to the control group $(p<0.05)$. As a result, it was concluded that up to $25 \%$ of egg powder can be used rainbow trout fry feeds, but continuous feeding with egg powder supplemented feeds may cause fish health problems.

Keywords: Egg powder, growth performance, Lactococcus garvieae, Oncorhynchus mykiss, Yersinia ruckeri, protein

Öz: Bu çalışma, gökkuşağı alabalığı (Oncorhynchus mykiss) yavrularının $(0.38 \pm 0.01 \mathrm{~g}$ ve $3.55 \pm 0.05 \mathrm{~cm})$ geliş̧im performansını olumsuz etkilemeden protein açığını kapatmak için balık ununa ikame edilebilecek uygun yumurta tozu oranını belirlemeyi amaçlamaktadır. Ayrıca gökkuşağı alabalığı yemlerinde protein kaynağı olarak kullanılan yumurta tozunun büyüme performansı, yemden yararlanma, vücut kompozisyonu ve yaşama oranları üzerindeki etkileri de araştııımıştır. Grupların rasyonlarındaki yumurta tozu oranı balık unundan elde edilen protein mikranının \%0 (Kontrol), \%25 ( $E-25)$, \%50 ( $E-50)$, \%75 (E-75) ve \%100 (E-100) olacak şekilde hazırlandı. Gelişim permanslarının değerlendirilmesi için Mart - Mayıs ayları arasında 90 gün boyunca beslenen balıklara, challenge testi için ise 17 gün ilave yemleme yapııdı. Çalışmanın sonunda, rasyona \%25 den daha fazla yumurta tozu ilavesinin ağırık kazancı (AA), ağırıı artışı oranı (AAO), spesifik büyüme oranı (SBO), yem alımı (YA) ve protein değerlendirme oranı (PDO) bakımından gruplar arasında farklılaşmaya yol açtığı tespit edildi $(p<0,05)$. Gruplar arasındaki farkın kondisyon faktörü $(K F)$ açısından önemsiz olduğu ve rasyona \%25'ten fazla yumurta tozu eklenmesinin, yem dönüşüm oranını (YDO) anlamlı olarak artırdığı belirlendi ( $p<0.05)$. İki farkı balık patojeniyle (Lactococcus garvieae ve Yersenia ruckeri) yapılan challenge testi sonucunda, yumurta tozu ilavesinin tüm gruplarda kontrol grubuna oranla yaşama yüzdesini düşürdüğü belirlendi. Sonuç olarak, gökkuşağı alabalığı yavru yemlerinde \%25'e kadar yumurta tozunun kullanılabileceği, ancak yumurta tozu takviyeli yemlerle sürekli beslenmenin balık sağlığı sorunlarına neden olabileceği sonucuna varılmıştır.

Anahtar kelimeler: Büyüme performansı, Lactococcus garvieae Oncorhynchus mykiss, yumurta tozu, Yersinia ruckeri, protein

\section{INTRODUCTION}

The demand for animal protein is increasing day by day with the increase of the world population, increasing the welfare level of people, and spreading awareness of healthy nutrition. Fish is the most profitable product for consumers to meet this animal protein requirement. With the increase in protein demand, the animal husbandry sector is growing rapidly and this situation increases the amount of feed required. According to FAO (2018) the aquaculture sector, which has a growth rate of $5.8 \%$ between 2001 and 2016, brought about growth in the feed sector. In 2016, world 
compound feed production reached a record level with 1 billion 32 million tons of production (Dünya Karma Yem Pazarı, 2018). According to 2018 data, the share of fish feed in the world compound feed production is $4 \%$ (Türkiyem-Bir, 2019).

Fish feed required for aquaculture is largely dependent on fish meal and fish oil production. Since the annual production of fish meal and fish oil is almost constant, it is likely to pose a problem in the coming years (FAO, 2002; Petterson, 2010) Fish meal is the most commonly used component in animal feeds as a source of animal protein. Fish meal and fish oil are obtained from fish which are obtained from fishing activities and not offered for human consumption (Erdogan, 2008). However, against the increasing demand, fish meal, and fish oil production obtained by fishing activities can no longer meet the demand. This situation has led to an increase in fish meal and fish oil prices. Excessively high prices have led researchers to search for different protein sources in fish feeds (Akiyama et al., 1995; Erdogan, 2008).

In terms of biological value, when egg protein is compared to other foodstuffs, it comes first with 95\% digestibility (Çopur et al., 2004; Çelebi and Karaca, 2006). Due to the good amino acid content of egg protein, its biological value has been accepted as 100 and reported to be used as a reference value for other foodstuffs in food quality analyses (Hasipek and Aktaş, 1997; Çelebi and Karaca, 2006). The albumen and yolk of the egg, which are very rich in vitamins and minerals, have different concentrations of vitamins and minerals. Egg yolk is rich in vitamin A, Vitamin D, Vitamin E, biotin, riboflavin, choline, thiamine, and pantothenic acid, while the albumen is rich in niacin. In terms of mineral content, albumen contains $\mathrm{Na}^{+}, \mathrm{K}^{+}, \mathrm{Cl}^{+}, \mathrm{S}^{++}, \mathrm{Mg}^{++}$, while egg yolk contains $\mathrm{Fe}^{++}, \mathrm{Cu}^{++}, \mathrm{Ca}^{++}, \mathrm{P}^{++}, \mathrm{Zn}^{++}$. Vitamin $\mathrm{C}$ is not found in eggs, (Hasipek and Aktaş, 1997; Çelebi and Karaca, 2006).

This study aims to determine the appropriate egg powder ratio, which is easier to find compared to fish meal, can be substituted into the fish meal to close the protein deficit without adversely affecting the development performance of rainbow trout fry. Also, the effects of using different amounts of egg powder in rainbow trout fry diets on growth performance, feed yield, body composition, and survival rates of rainbow trout fry were investigated. In addition, the effects of the addition of egg powder on the survival rate of fry fish were determined by applying a challenge test against two different fish pathogens (Lactococcus garvieae and Yersinia ruckeri).

\section{MATERIALS AND METHODS}

\section{Experiment area and fish material}

The fish material used in the study was obtained from Recep Tayyip Erdogan University lyidere Application and Research Center. The study, which continued for 90 days between March and May 2019 for evaluation of growth performance and 17 days for the experiment of challenge test, was carried out in the same center. For this purpose, 1500 rainbow trout (Oncorhynchus mykiss) fry between 0.31 and $0.50 \mathrm{~g}$ (mean $0.38 \pm 0.01 \mathrm{~g}$ ) and between 3.45 and 3.65 $\mathrm{cm}$ (mean $3.55 \pm 0.05 \mathrm{~cm}$ ) were used in the study. The fish were placed in $80 \mathrm{~L}$ fiberglass tanks with 100 fish in each tank and 5 groups (control, E-25, E-50, E-75, and E-100) were created in $3 \times 5$ systems, each assigned randomly. In the study carried out in an indoor environment, additional lighting was made with the white light-producing LED bulb (Philips Essential Led Bulb 14W-100W 16 hours). For all the groups to benefit from an equal amount of light source, the hanging distance of LED bulbs from the tank surface was adjusted by using MASTEC Ms 6610 brand lux meter (200 lux each tank). In the study, 16 hours of light and 8 hours dark were applied to the experimental groups.

\section{Preparation of egg powder}

In the study, chicken eggs weighing between $\geq 53$ and $<63 \mathrm{~g}$ (Medium size) and classified in the category of class A eggs specified in the Turkish Food Codex Egg notification were used (Türk Gıda Kodeksi, 2014). The total weights of 240 eggs (14580.32 g) obtained from a local shop and the interior weight after breaking (12375.44 g) were weighted. After all the eggs were broken into a deep bowl, the albumen and egg yolk were homogenized by mixing with an electronic kitchen blender. Homogenized egg material was poured into impermeable industrial type baking trays made of steel material not to exceed $1 \mathrm{~cm}$ in depth. The trays were placed in the industrial feed drying oven (POL-EKO-APARATURA SP. J. SLW 400 STD) and stored at $55{ }^{\circ} \mathrm{C}$ about 2-3 days until moisture was removed. The dried egg material was ground with an industrial kitchen type feed grinding machine. The egg material, which was ground and powdered, was sieved through a sieve with a $500 \mu \mathrm{m}$ mesh. The obtained egg powder $(3004 \mathrm{~g})$ was packaged with clip-on kitchen bags and stored at $-18^{\circ} \mathrm{C}$.

\section{Experimental feeds and the design of feed groups}

The feed ingredients (fish meal, fish oil, soybean meal, corn gluten meal, and bonkalit) and binder were obtained from KAGSAN Black Sea Food and Agriculture Industry Inc in Trabzon-Turkey and Turhal Sugar Factory in Tokat-Turkey, respectively. The amino acid contents of fish meal (anchovy powder), and egg powder and the fatty acid contents of egg powder has been analyzed by the Kazlıçesme R\&D Test Laboratories with the In-House method. The amino acid 
values of soybean meal, corn gluten, bonkalite, and the fatty acid values of the fish meal were given based on the literature research (Table 1 and Table 2). The formulation of the basal diets is given in Table 3. Fish meal, soybean meal, egg powder, and corn gluten were used as dietary protein sources. Fish oil and crude lipid of egg powder was used as lipid sources. Contest of crude protein, crude lipid, and ash were $47.56 \pm 0.26 \%, \quad 19.25 \pm 0.18 \%$, and $7.23 \pm 0.6 \%$, respectively, and formulation has been shown to be nutritionally adequate for growth for rainbow trout (Oncorhynchus mykiss). $60 \%$ of the protein source in the diets was arranged to provide from the animal protein source and the remaining $40 \%$ from the plant protein source. The egg powder ratio in the groups was arranged to be $25 \%$ (E25), $50 \%(E-50), 75 \%(E-75)$, and $100 \%$ (E-100) of the existing animal protein source. All the feed ingredients were ground into powder, sieved through a sieve with $500 \mu \mathrm{m}$ mesh size, and thoroughly mixed with fish oil. To this $400 \mathrm{~g}$ $\mathrm{kg}^{-1}$ water of diet was added and kneaded. The formed doughy material was passed through metal sieves of $500 \mu \mathrm{m}$, $800 \mu \mathrm{m}, 1 \mathrm{~mm}$, and $2 \mathrm{~mm}$, and pellets were obtained in sizes that the fish could eat. The pellets formed were dried at $60{ }^{\circ} \mathrm{C}$ for 12-24 hours until the moisture rates dropped below $10 \%$ and the prepared feeds were stored at $+4^{\circ} \mathrm{C}$.

Table 1. Amino acid content of feed ingredients (\%)

\begin{tabular}{lccccc}
\hline Amino acids & $\begin{array}{c}\text { Fish } \\
\text { meal }\end{array}$ & $\begin{array}{c}\text { Egg } \\
\text { powder }\end{array}$ & Bonkalit & $\begin{array}{c}\text { Corn } \\
\text { gluten }\end{array}$ & $\begin{array}{c}\text { Soybean } \\
\text { meal }\end{array}$ \\
\hline Arginine & 7.8 & 3.5 & $0.92^{*}$ & $2.08^{*}$ & $0.18^{* *}$ \\
Lysine & 7.9 & 4.4 & $0.67^{*}$ & $1.01^{*}$ & $4.48^{* *}$ \\
Histidine & 2.6 & 1.4 & $0.38^{*}$ & $1.40^{*}$ & $1.19^{* *}$ \\
Isoleucine & 4.2 & 5.0 & $0.67^{*}$ & $2.54^{*}$ & $2.30^{* *}$ \\
Leucine & 7.1 & 5.3 & $1.08^{*}$ & $10.3^{*}$ & $3.36^{* *}$ \\
Methionine & 3.1 & 4.5 & $0.18^{*}$ & $1.37^{*}$ & $0.39^{* *}$ \\
Phenylalanine & 3.6 & 6.5 & $0.64^{*}$ & $3.68^{*}$ & $2.18^{* *}$ \\
Threonine & 4.0 & 2.5 & $0.54^{*}$ & $2.22^{*}$ & $4.78^{* *}$ \\
Tryptophan & 1.1 & 5.0 & - & $0.30^{*}$ & - \\
Valine & 7.9 & 3.0 & $0.75^{*}$ & $3.09^{*}$ & $2.41^{* *}$ \\
Proline & 2.08 & 1.5 & & $0.84^{* * *}$ & $2.42^{* * *}$ \\
Hydroxyproline & - & 1.0 & & - & - \\
Sarcosine & - & 3.5 & & - & - \\
Tyrosine & 2.32 & 3.5 & & $3.29^{* * *}$ & $1.67^{* * *}$ \\
Alanine & 4.67 & 2.0 & & $5.75^{* * *}$ & $2.08^{* * *}$ \\
Glycine & 3.66 & 1.0 & & $1.85^{* * *}$ & $2.03^{* * *}$ \\
Glutamine & 9.87 & 2.5 & & - & - \\
Serine & 3.05 & 4.6 & & $3.65^{* * *}$ & $2.56^{* * *}$ \\
Asparagine & - & 5.0 & & - & - \\
Cystine & 0.15 & 7.5 & & $0.59^{* * *}$ & $0.71^{* * *}$ \\
Aspartate & 7.51 & 5.0 & & $3.49^{* * *}$ & $6.70^{* * *}$ \\
Glutamate & - & 10.5 & & $13.5^{* * *}$ & $8.91^{* * *}$ \\
\hline
\end{tabular}

"NRC, (1993); " "Prado et al., (2016); "'Leme et al., (2019)
Table 2. Fatty acid composition of egg powder used in the experiments (\%)

\begin{tabular}{|c|c|c|}
\hline Fatty acids & Egg Powder (g/100g) & Fish meal (\%) \\
\hline $\mathrm{C} 12: 0$ & 0.002 & 0.09 \\
\hline C13:0 & nd & 0.06 \\
\hline $\mathrm{C} 14: 0$ & 0.017 & 5.40 \\
\hline C15:0 & 0.05 & 1.12 \\
\hline $\mathrm{C} 16: 0$ & 0.16 & 20.30 \\
\hline C17:0 & 0.02 & 1.36 \\
\hline C18:0 & 0.04 & 4.32 \\
\hline $\mathrm{C} 20: 0$ & 0.02 & 0.11 \\
\hline $\mathrm{C} 21: 0$ & nd & 0.17 \\
\hline C22:0 & 0.01 & 0.18 \\
\hline $\mathrm{C} 23: 0$ & nd & 0.10 \\
\hline $\mathrm{C} 24: 0$ & nd & 0.24 \\
\hline$\sum$ SFA & 0.319 & 33.44 \\
\hline C14:1 & 0.005 & 0.19 \\
\hline C15:1n-5 & nd & 0.04 \\
\hline C16:1n-7 & 0.02 & 5.24 \\
\hline C17:1n-7 & nd & 0.04 \\
\hline C18:1n-9t & 0.36 & 0.15 \\
\hline C18:1n-9c & 1.40 & 12.96 \\
\hline C20:1n-9 & 0.014 & 1.25 \\
\hline C22:1n-9 & 0.02 & 0.23 \\
\hline C24:1n-9 & nd & 0.87 \\
\hline$\sum$ MUFA & 1.864 & 20.96 \\
\hline C18:2n-6t & 0.20 & 0.20 \\
\hline$C 18: 2 n-6 c$ & 0.37 & 1.62 \\
\hline C18:3n-6g & 0.015 & 0.13 \\
\hline C18:3n-3a & 0.01 & 1.00 \\
\hline$C 20: 2 n-6$ & nd & 0.26 \\
\hline C20:3n-3 & nd & 0.10 \\
\hline$C 20: 4 n-6$ & 0.03 & 1.23 \\
\hline C20:5n-3 & 0.01 & 7.86 \\
\hline$C 22: 2 n-6$ & nd & 1.05 \\
\hline C22:6n-3 & 0.018 & 18.32 \\
\hline$\sum$ PUFA & 0.653 & 31.76 \\
\hline$\sum n-3$ & 0.038 & 27.28 \\
\hline$\sum n-6$ & 0.615 & 4.48 \\
\hline$n-3 / n-6$ & 0.061 & 6.13 \\
\hline
\end{tabular}

Note: Fatty acid values of the fish meal were rearranged by averaging the values reported by Turan et al., (2007).

SFA: saturated fatty acid. MUFA: monounsaturated fatty acid. PUFA: polyunsaturated fatty acid. nd: not detected 
Table 3. Formulation of experimental diets $\left(\mathrm{g} \mathrm{kg}^{-1}\right)$

\begin{tabular}{lccccc}
\hline Ingredients & Control Diet & E-25 Diet & E-50 Diet & E-75 Diet & E-100 Diet \\
\hline Fish meal & 390 & 280 & 210 & 120 & 0 \\
Soybean meal & 150 & 150 & 150 & 140 & 150 \\
Egg powder & & 150 & 260 & 400 & 550 \\
Corn gluten & 140 & 140 & 140 & 140 & 150 \\
Bonkalit & 150 & 150 & 140 & 140 & 130 \\
Fish oil & 150 & 110 & 80 & 40 & 0 \\
Vitamin premix & 5 & 5 & 5 & 5 & 5 \\
Mineral premix & 5 & 5 & 5 & 5 & 5 \\
Molasses & 10 & 10 & 10 & 10 & 10 \\
\hline
\end{tabular}

Mineral and vitamin premix porvided by Farmavet International Pharmaceutıcal Industry and Trade Inc.. Manisa/Salihli/TURKEY.

a Vitamin premix provides the following (mg 10kg-1 diet): Vitamin A (300000 IU) $90 \mathrm{mg}$. Vitamin $\mathrm{D}_{3}(300000 \mathrm{IU}) 7.5 \mathrm{mg}$. Vitamin E (6000 IU) $4000 \mathrm{mg}$. Vitamin $\mathrm{K}_{3}$ $450 \mathrm{mg}$. Vitamin $B_{1} 1900 \mathrm{mg}$. Vitamin $B_{2} 1000 \mathrm{mg}$. Vitamin $B_{6} 850 \mathrm{mg}$. Vitamin $B_{12} 4 \mathrm{mg}$. Niacin $2000 \mathrm{mg}$. folic acid $2.5 \mathrm{mg}$. Biotin $800 \mathrm{mg}$

${ }^{b}$ Mineral premix provides the following (mg 10kg-1 diet): calcium (Ca) $150 \mathrm{mg}$. phosphorus (P) $40 \mathrm{mg}$. magnesium (Mg) $53 \mathrm{mg}$. sulfur (S) $300 \mathrm{mg}$. sodium (Na) $280 \mathrm{mg}$. molybdenum (Mo) $100 \mathrm{mg}$. iodine (I) $13 \mathrm{mg}$. cobalt (Co) $10 \mathrm{mg}$. selenium (Se) $130 \mathrm{mg}$. copper (Cu) $2400 \mathrm{mg}$. Iron (Fe) $8000 \mathrm{mg}$. zinc (Zn) $7200 \mathrm{mg}$. manganese $(\mathrm{Mn}) 7000 \mathrm{mg}$.

\section{Proximate analysis of experimental diets and ingredients.}

Proximate analyses were performed in the aquaculture laboratories of Recep Tayyip Erdoğan University. Crude protein, crude lipid, moisture, and ash in the experimental diet and ingredients were determined according to established methods of AOAC 2005 (Berbert et al., 2005). Moisture was determined by drying to constant weight at $105^{\circ} \mathrm{C}$, crude protein $(\mathrm{N} \times 6.25)$ was determined by Kjeldahl method using by Behr Distillation Unit S5, and lipid was determined by petroleum-ether (B.P. $30-60^{\circ} \mathrm{C}$ for $2 \mathrm{~h}$ ) using Velp SER 148/6
(Velp Scientifica. Milano. Italy). For ash content analysis, samples were placed in a muffle furnace (ŞiMŞEK Laborteknik KF-908) at $550{ }^{\circ} \mathrm{C} 6 \mathrm{~h}$.

Crude cellulose analysis was performed according to Feed Inspection and Analysis Methods Communiqué No: 91/20 (Yem Muayene Analiz Metotları, 1992). Nutritional values of the experimental diets and feed ingredients obtained as a result of proximate analyses were given in Table 4 and Table 5.

Table 4. Nutritional value of experimental diets (\% of wet weight)

\begin{tabular}{lccccc}
\hline Nutrition level & Control Diet & E-25 Diet & E-50 Diet & E-75 Diet & E-100 Diet \\
\hline Crude protein & 47.82 & 47.63 & 47.21 & 47.76 & 47.39 \\
Crude lipid & 19.51 & 19.30 & 19.24 & 19.20 & 19.01 \\
Moisture & 8.71 & 8.62 & 8.38 & 8.43 & 8.11 \\
Ash & 6.96 & 7.46 & 7.96 & 7.31 & 6.46 \\
NFE & 17.00 & 16.99 & 17.21 & 17.30 & 19.03 \\
Gross enegy (kj g-1 diet) & 21.65 & 21.78 & 21.70 & 21.83 & 21.96 \\
P:E (mg/kJ) & 22.11 & 21.86 & 21.75 & 21.87 & 21.58 \\
\hline
\end{tabular}

NFE $=100$-(crude protein + crude lipid + moisture + ash)

Gross energy was calculated based on $1 \mathrm{~g}$ crude protein being $23.6 \mathrm{~kJ}, 1 \mathrm{~g}$ crude fat being $39.5 \mathrm{~kJ}$ and $1 \mathrm{~g}$ carbohydrate being $17.2 \mathrm{~kJ}(\mathrm{NRC}, 1993)$. $P: E=($ crude protein $/$ Gros energy $) \times 1000$

Table 5. Proximate analysis of feed ingredient (\%)

\begin{tabular}{lccccc}
\hline Ingredient & Fish meal & Egg powder & Soybean meal & Corn gluten & Bonkalit \\
\hline Crude protein & 70.00 & 49.5 & 45.50 & 64.00 & 14.30 \\
Crude lipid & 8.10 & 34.5 & 2.80 & 2.25 & 2.10 \\
Moisture & 9.40 & 10.25 & 11.10 & 8.90 & 9.50 \\
Ash & 7.90 & 1.50 & 6.21 & 1.70 & 1.55 \\
Crude cellulose & 0.15 & 0 & 4.35 & 1.90 & 9.31 \\
NFE & 4.45 & 4.25 & 30.04 & 21.25 & 63.24 \\
\hline
\end{tabular}

NFE (Nitrogen free extract) $=100-($ Crude protein + Crude lipi + Crude cellulose + Moisture + Ash $)$ 


\section{Collection of data and calculation of growth performance}

Fish were fed four times a day $(9: 00 \mathrm{~h}, 12: 00 \mathrm{~h}, 15: 00 \mathrm{~h}$, and 18:00 h) depending on the water temperature and fish weight (5\% of fish weight) in all groups. Length and weight measurements were performed in experimental groups every 15 days. Weight measurements were made with $\pm 0.1 \mathrm{~g}$ precision scales and length measurements with $\pm 1 \mathrm{~mm}$ precision von Bayer (Piper et al., 1982). No anesthetic substance was applied to the fish during the data collection phase. Growth parameters were calculated as per the following formulae:

Weight gain (WG, $g$ ) = (initial body weight, $g-$ final body weight, g);

Weight gain rate $(W G R, \%)=100 \times$ [final body weight, $g$ initial body weight, g) / initial body weight, g] (Shiau and Chen, 1992);

Feed conversion ratio $(F C R)=$ dry feed consumed, $g /$ wet weight gain, g (Imsland et al., 2001);

Specific grow rate $\left(S G R, \%\right.$ day $\left.{ }^{-1}\right)=100 \times$ [In (final body weight, g) - In (initial body weight, g) / days] (Hopkins, 1992);

Protein efficiency ratio $(P E R)=$ wet weight gain $/$ protein intake (Mohseni et al., 2011);

Condition factor $\left(\mathrm{CF}, \mathrm{g} / \mathrm{cm}^{3}\right)=100 \times[($ body weight, g) $/$ (body length, $\mathrm{cm})^{3}$ ] (Avsar, 2005);

Survival Rate $(S R, \%)=100 \times$ [final number of fish $/$ initial number of fish] (Çelikkale, 2002).

\section{Challenge test}

After 7 days of the end of the study, 5 test groups with 3 replications were created for the challenge test (Control, E-25, $\mathrm{E}-50, \mathrm{E}-75$, and E-100). 10 fish (mean $5.97 \pm 0.49 \mathrm{~g}$, $4.53 \pm 0.30$ g, $3.71 \pm 0.38$ g, $3.26 \pm 0.14$ g, $2.55 \pm 0.24$, respectively) were placed in each $80 \mathrm{~L}$ tank. Lactococcus garvieae and Yersinia ruckeri were obtained from the fish diseases laboratory of the Fisheries and Aquaculture Faculty of Recep Tayyip Erdogan University. The bacteria were incubated for 24 hours at TSB broth and then centrifuged. The supernatant was discarded and the bottom bacteria were mixed with sterile FTS and brought to turbidity Mac-Farland: 0.5 and prepared for injection. All fish were injected intraperitoneally with $0.1 \mathrm{ml}$ bacterial suspension (L. garvieae $2.4 \times 10^{8} \mathrm{CFU} / \mathrm{mL} ;$ Y. ruckeri $3.6 \times 10^{8} \mathrm{CFU} / \mathrm{mL}$ ) using medical insulin syringes according to our preliminary experiment. Fish continued to receive four times a day with their experimental diets after injection. Fish were monitored three times daily and mortality was recorded. After the deaths stopped the observation continued for 3 more days and the study was terminated on the 10th day. Survival rate was determined and bacteria were confirmed after reisolating them from the dead fish.

\section{Statistical analysis}

Results are presented with mean $\pm S D$ of three replicates. Sigma Plot 11.0 package programs were used so as to evaluate the findings of the present study. All data were subjected to one-way analysis of variance (ANOVA) followed by TUKEY's multiple range test. P-value of $<0.05$ was considered significant.

\section{RESULTS}

\section{Environmental conditions}

During the experimental period for 90 days, the minimum and maximum values of water temperature, dissolved oxygen, and $\mathrm{pH}$ were measured $12.92 \pm 1.61^{\circ} \mathrm{C}\left(\min 8^{\circ} \mathrm{C}, \max 16^{\circ} \mathrm{C}\right)$, $7.1 \pm 0.4 \mathrm{mg} / \mathrm{L}$ ( $\min 6.7 \mathrm{mg} / \mathrm{L}$, $\max 7.5 \mathrm{mg} / \mathrm{L}$ ), and $7.55 \pm 0.25$ ( $\min 7.3, \max 78)$ respectively.

The effect of egg powder on growth performance, and feed utilization of rainbow trout fry

The comparison of the given data on the final body weight (FBW), weight gain (WG), weight gain rate (WGR), specific growth rate (SGR), feed intake (FI), feed conversion ratio $(F C R)$, the protein efficiency ratio (PER), condition factor (CF) and survival rate (SR) of rainbow trout fry fed with the different experimental diets were shown in Table 6 . The WG determined in experimental groups throughout the study is given in Figure 1. According to the results of the tests, the difference in the mean values of the above indices among the experimental groups compared to the control group was statistically significant $(p<0.05)$. The highest FBW, WG, WGR, $S G R$, and PER were recorded on the Control diet, while the highest $\mathrm{FI}$ and $\mathrm{CF}$ were recorded on $\mathrm{E}-25$ and $\mathrm{E}-75$ groups, respectively. The FBW, WG, and WGR of fish fed E-25, E-50, $E-75$, and $E-100$ were significantly lower $(p<0.05)$ than the fish fed control. The SGR values decreased significantly with increasing egg powder ratio in experimental groups $(p<0.05)$. The FCR and PER values increased significantly with increasing egg powder ratio in diet groups $(p<0.05)$. The best FCR value was determined in the control, while the worst was determined in the E-100 diet. It was determined that the control, E-25, and E-50 are statistically similar to each other; and E-25, E-50, and E-75 are statistically similar to each other; E-75 and E-100 are statistically similar with each other $(p<0.05)$. The PER values of the control and E-100 diets were significantly different from all the other groups, while the $E-25$ and $\mathrm{E}-50$ were statistically similar to each other, and E-50 and E-75 groups were statistically similar with each other $(p<0.05)$. There were no significant differences in CF among all experimental groups. The best SR value was determined in the E-100 diet while the worst was determined in the control diet. For the SR, E-50 and E-75 diets were determined to be statistically similar, while all the other groups were determined to be statistically different from each other $(p<0.05)$ (Figure 2). 
Köse et al., Ege Journal of Fisheries and Aquatic Sciences, 38(1), 69-78 (2021)

Table 6. Effects of egg powder on growth performance, feed utilization and survival rate in rainbow trout fry

\begin{tabular}{llllll}
\hline & Control & E-25 & E-50 & E-75 & E-100 \\
\hline IBW (g) & $0.38 \pm 0.05^{\mathrm{a}}$ & $0.38 \pm 0.05^{\mathrm{a}}$ & $0.38 \pm 0.05^{\mathrm{a}}$ & $0.38 \pm 0.06^{\mathrm{a}}$ & $0.38 \pm 0.07^{\mathrm{a}}$ \\
FBW $(\mathrm{g})$ & $5.75 \pm 0.09^{\mathrm{a}}$ & $4.89 \pm 0.09^{\mathrm{b}}$ & $3.92 \pm 0.07^{\mathrm{c}}$ & $3.39 \pm 0.17^{\mathrm{d}}$ & $2.58 \pm 0.10^{\mathrm{e}}$ \\
IBL $(\mathrm{cm})$ & $3.57 \pm 0.07^{\mathrm{a}}$ & $3.47 \pm 0.03^{\mathrm{a}}$ & $3.58 \pm 0.07^{\mathrm{a}}$ & $3.56 \pm 0.03^{\mathrm{a}}$ & $3.58 \pm 0.05^{\mathrm{a}}$ \\
FBL (cm) & $8.21 \pm 0.77^{\mathrm{a}}$ & $7.13 \pm 0.46^{\mathrm{ab}}$ & $6.98 \pm 0.08^{\mathrm{cb}}$ & $6.47 \pm 0.17^{\mathrm{cb}}$ & $5.91 \pm 0.17^{\mathrm{c}}$ \\
WG (g) & $5.37 \pm 0.09^{\mathrm{a}}$ & $4.51 \pm 0.09^{\mathrm{b}}$ & $3.54 \pm 0.13^{\mathrm{c}}$ & $3.01 \pm 0.30^{\mathrm{d}}$ & $2.20 \pm 0.17^{\mathrm{e}}$ \\
WGR (\%) & $1394.82 \pm 25.86^{\mathrm{a}}$ & $1170.74 \pm 23.06^{\mathrm{b}}$ & $910.97 \pm 37.92^{\mathrm{c}}$ & $774.85 \pm 74.96^{\mathrm{d}}$ & $540.07 \pm 26.28^{\mathrm{e}}$ \\
SGR $\left(\%\right.$ day- $\left.^{-1}\right)$ & $3.00 \pm 0.02^{\mathrm{a}}$ & $2.82 \pm 0.02^{\mathrm{ba}}$ & $2.57 \pm 0.04^{\mathrm{c}}$ & $2.40 \pm 0.09^{\mathrm{c}}$ & $2.06 \pm 0.08^{\mathrm{d}}$ \\
FI (g) & $415.25 \pm 7.12^{\mathrm{a}}$ & $685.82 \pm 23.91^{\mathrm{b}}$ & $546.49 \pm 23.27^{\mathrm{c}}$ & $582.44 \pm 6.09^{\mathrm{c}}$ & $479.00 \pm 19.67^{\mathrm{d}}$ \\
FCR & $1.38 \pm 0.10^{\mathrm{a}}$ & $1.47 \pm 0.34^{\mathrm{ab}}$ & $1.68 \pm 0.19^{\mathrm{ab}}$ & $1.90 \pm 0.22^{\mathrm{bc}}$ & $2.30 \pm 0.22^{\mathrm{c}}$ \\
PER & $2.83 \pm 0.00^{\mathrm{a}}$ & $1.46 \pm 0.06^{\mathrm{b}}$ & $1.33 \pm 0.05^{\mathrm{bc}}$ & $1.21 \pm 0.11 \mathrm{c}$ & $0.96 \pm 0.03^{\mathrm{d}}$ \\
CF & $1.00 \pm 0.21^{\mathrm{a}}$ & $1.03 \pm 0.12^{\mathrm{a}}$ & $0.99 \pm 0.18^{\mathrm{a}}$ & $1.04 \pm 0.22^{\mathrm{a}}$ & $1.01 \pm 0.20^{\mathrm{a}}$ \\
SR (\%) & $50.0 \pm 1.00^{\mathrm{a}}$ & $60.33 \pm 1.15^{\mathrm{b}}$ & $81.67 \pm 2.89^{\mathrm{c}}$ & $85.33 \pm 1.53^{\mathrm{c}}$ & $92.67 \pm 2.89^{\mathrm{d}}$ \\
\hline
\end{tabular}

Data are expressed as mean $\pm S D$. Values in the same row with different superscripts are significantly different $(p<0.05)$.

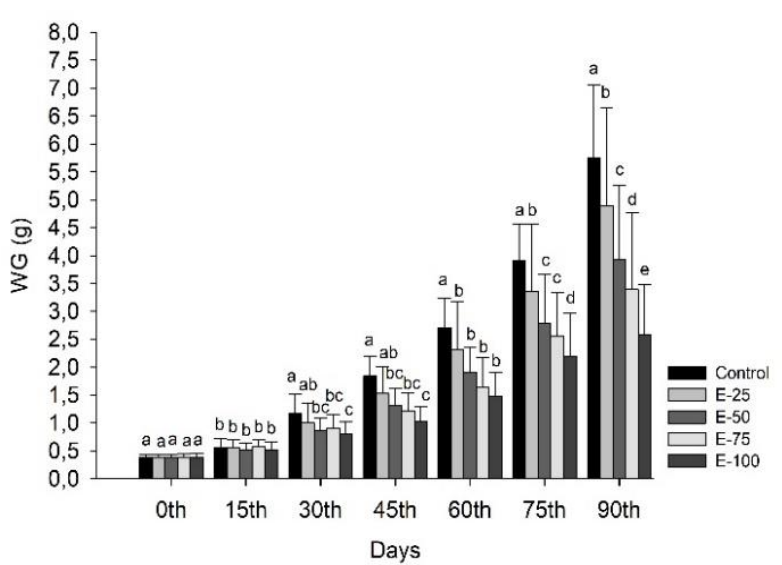

Figure 1. The periodic weightgain of the groups. Data are expressed as mean $\pm S D$. Values not sharing a common superscript are significantly different in the same period $(\mathrm{P}<0.05)$

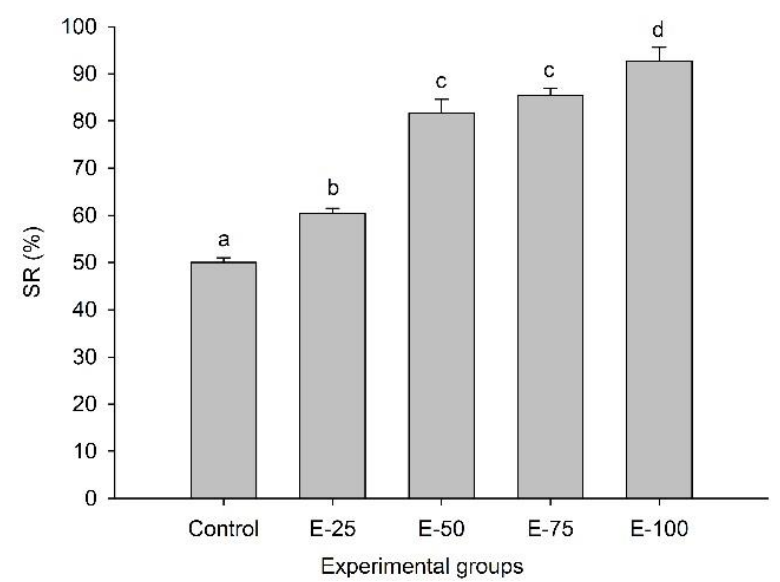

Figure 2. The survival rate of the groups as a result of the end of the study. Data are expressed as mean $\pm S D$. Values not sharing a common superscript are significantly different $(p<0.05)$
The effect of egg powder levels on challenge test of rainbow trout fry

The challenge test showed that the highest survival rate was observed in the control diet of both Lactococcus garvieae (Figure 3) and Yersinia ruckeri (Figure 4).

The SR in control, E-25, E-50, E-75 and E-100 were determined to be $46.7 \pm 5.8 \%, 30.0 \pm 10.0 \%, 20.0 \pm 10.0 \%$, $16.7 \pm 5.8 \%$ and $10.0 \pm 10.0 \%$ respectively, against Lactococcus garvieae and $23.3 \pm 5.8 \%, 16.7 \pm 5.8 \%$, $13.3 \pm 5.8 \%, \quad 6.7 \pm 5.8 \%, \quad 3.3 \pm 5.8 \%$ respectively, against Yersinia ruckeri. It was determined that the dietary supplement with egg powder significantly decreased the survival rate compared to the control group. $(p<0.05)$.

\section{DISCUSSION}

The first of the two basic rules of aquaculture is to ensure similar environmental conditions with their natural environment for fish, and the second is to feed fish in a balanced manner (Karabulut et al., 2010).

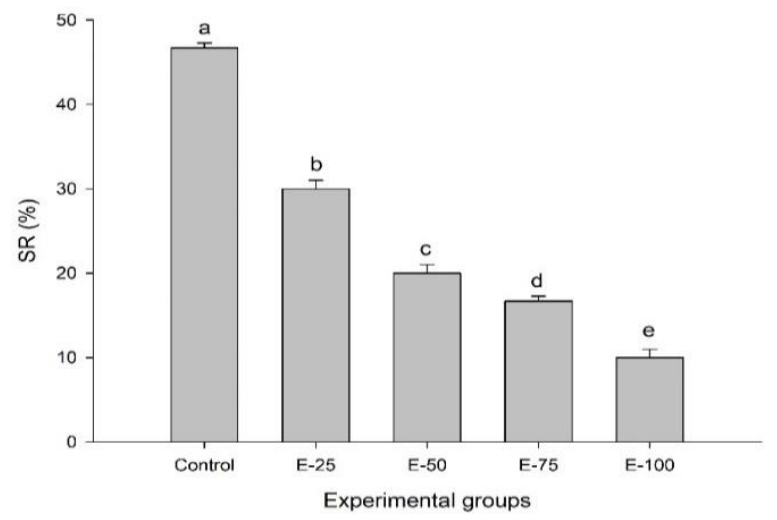

Figure 3. Effects of egg powder levels on the survival after Lactococcus garvieae $\left(2.4 \times 10^{8} \mathrm{CFU} / \mathrm{mL}\right)$ infection of fry rainbow trout on the 10th day. Data are expressed as mean $\pm S D$. Values not sharing a common superscript are significantly different $(p<0.05)$ 


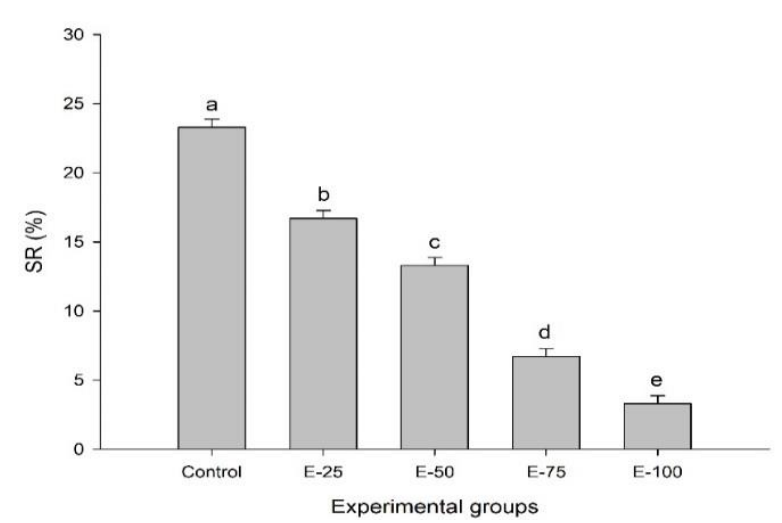

Figure 4. Effects of egg powder levels on the survival after Yersinia ruckeri $\left(3.6 \times 10^{8} \mathrm{CFU} / \mathrm{mL}\right)$ infection of rainbow trout fry on the 10th day. Data are expressed as mean \pm SD. Values not sharing a common superscript are significantly different $(p<0.05)$

The water temperature, dissolved oxygen, and $\mathrm{pH}$ values of rainbow trout were reported to be between $8-13^{\circ} \mathrm{C}, 7-11$ $\mathrm{mg} / \mathrm{L}$, and 6.5-8.5, respectively which were needed during the juvenile growth period (Çelikkale, 2002). The environmental parameter values obtained during these experimental studies are similar to those reported by Çelikkale (2002). Protein needs differ depending on fish species, but the protein content in feed rations for all fish should be at least $30 \%$ (Mills, 1989). It has been reported that the protein value that should be present in the rations of the carnivore fish species such as rainbow trout should be between 40-50\% (Edward, 1978). It has been reported that the ratio of oil in fish feed rations can be between $9.9-26 \%$, and crude ash rates can be between $7.6-13.43 \%$, depending on the fish species and growth stage (Gomes et al., 1993; Adelizi et al., 1998; Morris et al., 2005; Luo et al., 2006). While the protein ratios of the experimental feeds used in this study were compatible with the ratios stated in the literature, the ash ratios except for the E-50 diet group differed with low values. The difference between studies may have been due to the use of different protein sources and different feed rations.

Fish meal (FM) and fish oil (FO) is the most important protein and oil sources for aquaculture feed (aquafeed) due to the high protein content and a good balance of essential amino acids. Many fish nutritionists have researched new feed sources that may be an alternative to fish meal and fish oil in feed formulations or new additives that can increase growth and development. For instance, yeast-liver mixture, egg powder in the feeds of Cyprinus carpio larvae (AlamiDurante et al., 1991); Tubifex sp, yeast, milk powder, chicken eggs in the feeds of Clarias batrachus (Rahman et al., 1997); shrimp meal (SM), blood meal (BM), meat and bone meal (MBM), poultry by-product meal (PBM) in the feeds of Oreochromis niloticus (El-Sayed, 1998); crustacean waste products (CWP) in the feeds of Oncorhynchus mykiss (Özogul, 2000); SM, BM, meat meal (MM) in the feeds of Epinephelus coioides (Millamena, 2002); black soldier fly (BSF) in the feeds of Salmo salar (Lock et al., 2014); Gammarus spp in the feeds of Oncorhynchus mykiss
(Yeşilayer et al., 2016); tuna by-product meal (TBM) in the feeds of Sebastes schlegelihas has been tried as a source of protein (Kim et al., 2018).

In terms of SR, Alami-Durante et al. (1991) reported that the group fed with the feed prepared with yeast-liver mixer and egg powder achieved a higher SR than the group fed only with the feed prepared with yeast-liver mixer. El-Sayed (1998) reported that growth in fish fed with SM, PBM, MBM is significantly different from those fed with the FM diet, and FCR, PER significantly slowed down. Özogul (2000) stated that after the necessary amino acid is added to CWP, it can be used instead of FM. Millamena (2002) has reported that $\mathrm{MM}$ and MBM of terrestrial animal origin can be used instead of $80 \%$ of FM and there is no adverse effect on growth, SR, and FCR on the Epinephelus coioides juveniles. Kroeckel et al. (2012) stated that if high-level BSF is used in feed, the growth performance decreases for the Ictalurus punctatus, Oncorhynchus mykiss, and Psetta maxima. Lock et al. (2014) reported that using BSF instead of $25 \%, 50 \%$ and $100 \%$ of FM in Salmo salar feeds provides greater feed conversion efficiency. Yeşilayer et al. (2016) reported that the use of Gammarus spp in Oncorhynchus mykiss feeds did not differ significantly in the experimental groups in terms of GR, SGR, and FCR. Kim et al. (2018) has stated that TBM feed can be used instead of $75 \%$ of FM without growth and feed reduction.

In the present study, the effect of egg powder on the rainbow trout (Oncorhynchus mykiss) fry was evaluated in 90 days feeding trial. We observed a significant decrease of WG, WGR, SGR, FI, and PER in fish fed diets additional with egg powder for 90 days. The WG, WGR, SGR, FI, and PER of fish decreased significantly as egg powder levels increased from 0 to $100 \%$. Although the numerical results found are different, when the changes that occur as a result of the increase in the amount of different animal protein sources added to the feed rations instead of the fish meal, in terms of decreasing PER and SGR values and increasing FCR values are similar to the El-sayed (1998)'s study, but SR values are different. Millamena (2002) conducted a study with different animal protein sources instead of fish meal and created 9 different feed groups for this purpose. Millamena (2002) reported that WGR and SGR increased and FCR decreased in the feed groups diet-2, diet-3, diet-4, and diet-9. On the other hand, Millamena (2002) reported that SGR value decreased and FCR value increased in diet-5, diet-6, and diet-7 feed groups. The present study was found to be different from the reported changes in diet-2, diet- 3 , diet- 4 , and diet- 9 , but similar to those reported in diet- 5 , diet- 6 , and diet-7 feed groups. The SR change found in Millamena (2002)'s study is different from that in the present study. Goda et al. (2007) conducted studies with PBM and MBM. For this purpose, they prepared different levels of PBM and MBM feed groups. As a result, they reported that SGR and PER values decreased and FCR values increased in PBM-100, MBM-100, and MBM-75 
groups. In this respect, PBM-100, MBM-100, and MBM-75 groups are similar to the present study. On the other hand, they reported that SGR and PER values increased and FCR values decreased in the PBM-75 feed group. In this respect, the PBM-75 feed group is different from that in the present study. Kroeckel et al. (2012) conducted a study with BSF meal and reported that FI, SGR values decreased, FCR value increased, and CF values decreased significantly in all groups. FI, SGR, and FCR values showed similar changes in the present study, while CF showed different changes from those in the present study. Yeşilayer et al. (2016) conducted a study by adding Gammarus sp instead of fish meal. As a result of the study, they reported that WG, WGR, SGR, and FI values decreased, FCR value increased and $C F$ values did not have a statistical significance among the groups. These results are similar to the present study. Lock et al. (2016) conducted a study on Salmo salar with two different insect flour (IM-A and IM-B) produced from BSF. They reported that the $W G$ ratio decreased in $A 50, B 25$, and $B 100$ groups. While FCR value decreased in A50, A100, and B25 groups, it increased in the B100 group, and CF decreased statistically significantly in the B100 group. WG decrease and B100's FCR increase were similar to the present study, whereas B100's CF decrease was found to be different from the present study. Kim et al. (2018) conducted a study using Tuna by-product meal. They reported that WG and SGR values decreased in TBM50, TBM75, and TBM100 feed groups, while FCR values increased and PER values decreased in TBM75, TBM100 feed groups. These results are similar to the present study. On the other hand, the reported $\mathrm{FI}$ and SR values differed from the present study.

In the present study, the oil content in experimental feeds was adjusted by considering the crude oil content of the egg powder content. With the increase in the amount of egg powder, the amount of fish meal and fish oil in experimental feeds was decreased. According to the fatty acid analysis results of egg powder, it is seen that the $n-6$ series fatty acid group is more than the $n-3$ series. However, $n-6$ series fatty acids are not needed in trout diets (Cho and Covey, 1991; Hoşsu et al., 2012). Although the amino acid content of egg powder is close to the amino acid values of fishmeal, it may not be sufficient for the needs of trout in terms of essential fatty acid. In the present study, it is thought that the reason for the decreased fish development due to the increase in the amount of egg powder in experimental feeds is due to the insufficient fatty acid content of the fish trial feeds. In the cited literature studies, while different protein sources are tried in dietary contents, different oil sources were added and the differences that may arise from essential fatty acid deficiency are prevented. In the cited literature studies, the decrease in growth parameters results from the amino acid contents of the protein source and is not related to essential fatty acids.

On the 40th day of the present study, firstly, troubles and irregular swimming movements were noticed in the feed intake of the control group fish (other groups within the following 2-3 days). In the laboratory examination, Lactococcus garvieae was detected in fish and 14 days treatment was applied with Erythromycin application all groups. At the end of this study, the decrease in SR ratios in the control group and the increase of SR ratios with the increase in egg powder ratios in other experimental groups suggested the question of whether the egg had a protective effect. To answer this question, challenge tests were performed against Lactococcus garvieae and Yersinia ruckeri at the end of the present study.

Bacterial challenge tests are the most widely used and useful method to determine the effect of alternative substances added to the diet after nutritional experiments against fish pathogens (Austin and Zhang, 2006). Lactococcus garvieae is a gram-positive and immobile bacterium. It affects both natural fish species and cultured fish. It is a zoonotic pathogen that causes serious infections in humans and animals (Vendrell et al., 2006). In the present study, the highest SR rate was found in the control group $(46.7 \%)$ as a result of the challenge test against Lactococcus garvieae. The control group's SR rate was found to be similar to the values specified in the literature (Bark and McGregor, 2001; Eyngor et al., 2004; Vendrell et al., 2006). The rate of SR in other experimental groups was lower than the values indicated in the literature. Yersinia ruckeri is the cause of the disease known as Enteric red mouth (ERM) or Yersiniosis. Yersiniosis, which is a systemic bacterial disease, is one of the important diseases in farm fish, especially in Salmonids. It is $0.5-0.8 \times 1.0-3.0 \mu \mathrm{m}$ in gram-negative rod form (Gregory et al., 2010). It has been reported that acute epizootics can cause $30-70 \%$ death depending on environmental parameters and strain virulence (Furones et al., 1993; Noga, 2010). In the present study, it was found that the SR rate in the challenge test was relatively lower than the values specified in the literature.The reason for different results from the literature in both challenge tests has been linked to the size of the fish used, the injection dose, the used method, and the environmental parameters to be different. Uslu et al. (2019) reported that using $100 \%$ egg powder instead of the fish meal may decrease with the loss of appetite in fish and a decrease in growth performance. Also, they stated that there may be irregularities in blood parameters, kidney, and liver functions. As a result of the challenge test, another reason for the high mortality rates observed in egg powder supplemented feed groups may have been the reason in the notifications of Uslu et al. (2009).

\section{CONCLUSION}

As a result of this study, it has been concluded that the use of maximum $25 \%$ egg powder in the ration that will be created for the pre-feeding of rainbow trout fry will not have a negative effect on fish development. However, it has been concluded that increasing the egg powder usage rate will negatively affect the growth performance and feed evaluation values in rainbow trout fry development. Also, it has been concluded that the low SR ratio of the control group was caused by Lactococcus garvieae, and the usage of egg powder did not have a positive effect on fish disease resistance according to the result of the challenge test. The 
use of egg powders in trout diets must be researched by the researchers for effects on tissue development in vital organs such as the liver, spleen, kidney, and intestine along the feeding period.

\section{REFERENCES}

Adelizi, P.D., Rosati, R.R., Warner, K., Wu, Y.V., Muench, T.R., White, M.R. \& Brown. P.B. (1998). Evaluation of fish-meal free diets for rainbow trout. Aquaculture Nutrition, 4, 255-262. DOI: 10.1046/j.1365-2095.1998.00077.x

Akiyama, T., Unuma, T., Yamamoto, T., Marcouli, P. \& Kishi, S. (1995). Combinational use of malt protein flour and soybean meal as altenative protein sources of fingerling rainbow trout diets. Fisheries Science, 61 , 825-832. DOI: $10.2331 /$ fishsci.61.828

Alami-Durante, H., Charlon, N., Anne-Marie Escaffre, A.M. \& Bergot, P. (1991). Supplementation of artificial diets for common carp (Cyprinus carpio L.) larvae. Aquaculture, 93, 167-175. DOI: 10.1016/0044-8486(91)90215-S

Austin, B. \& Zhang, X.H. (2006). Vibrio harveyi: a significant pathogen of marine vertebrates and invertebrates. Letters in Applied Microbiology, 43, 119-124. DOI: 10.1111/j.1472-765X.2006.01989.x

Avsar, D. (2005). Balıkcılık Biyolojisi ve Populasyon Dinamiği. Nobel Kitabevi, ISBN: 9789758561445 , Adana, $332 \mathrm{~s}$.

Bark, S. \& McGregor, D. (2001). The first occurrence of lactococcosis in farmed trout in England. Trout News, 31, 9-11.

Berbert, D.M., Queiroz, E.C., \& Melo, A.O.A.C. (2005). Official methods of analysis of AOAC International. AOAC Official Method, 6, p 382.

Cho, C.Y. \& Cowey, C.B. (1991). Rainbow trout. Oncorhynchus mykiss, In: Wilson, R.P. (Ed), Handbook of Nutrient Requirements of Finfish, CRC Press, $p$ 131-143.

Çelebi, Ş. \& Karaca, H. (2006). Egg nutritional value, cholesterol content and studies on the nutritionally enriched egg with n-3 PUFAS. Atatürk University Journal of Agricultural Faculty, 37(2), 257-265.

Çelikkale, M.S. (2002). İ̧ Su Balıkları ve Yetiştiriciliği. Karadeniz Teknik Üniversitesi Sürmene Deniz Bilimleri Fakültesi Genel Yayın No:124. Cilt I, III Baskı. Trabzon, $419 \mathrm{~s}$.

Çopur, G., Duru, M. \& Şahin, A. (2004). Düşük kolesterollü yumurta üretimi yönünde yapılan çalışmalar. 4. Ulusal Zootekni Bilim Kongresi, 01-03 Eylül 2004, Isparta, s 48-52. Isparta: Süleyman Demirel Üniversitesi Bilgi Merkezi Mavi Kat, Yer Numarası:SF5 U111 2004.

Dünya Karma Yem Pazarı (2018). Retrieved from: http://www.feedplanetmagazine.com/dunya-karma-yem-pazari/

Edwards, D.J. (1978). Salmon and Trout Farming in Norway. Fishing News Books Ltd, ISBN: 0852380933, Farnham, Surrey, England 193 pp.

El-Sayed, A.F.M. (1998). Total replacement of fish meal with animal protein sources in Nile tilapia. Oreochromis niloticus (L.) feeds. Aquaculture Research, 29, 275-280. DOI:10.1046/j.1365-2109.1998.00199.x

Erdoğan. F. (2008). The use of alternatıve proteın sources in raınbow trout and its importance for the future of aquaculture. Süleyman Demirel Üniversitesi Eğirdir Su Ürünleri Fakültesi Dergisi, 4(1-2). 74-85.

Eyngor, M., Zlotkin, A., Ghittino, C., Prearo, M., Douet, D.G., Chilmonczyk, S. \& Eldar, A. (2004). Clonality and diversity of the fish pathogen Lactococcus garvieae in Mediterranean countries. Applied and Environmental Microbiology, 70, 5132-5137. DOI:10.1128/AEM. 70.9.5132-5137.2004

FAO. (2002). Use of fishmeal and fish oil in aquafeeds, further thoughts on the fishmeal trap. FAO Fisheries Circular No. 975, Food And Agrıculture Organızatıon Of The Unıted Natıons, Rome.

FAO. (2018). The state of world fisheries and aquaculture. Meeting The Sustainable Development Goal, Food And Agriculture Organization Of The United Nations, Rome.

Furones, M.D., Rodgers, C.J. \& Aunn, C.B. (1993). Yersinia ruckeri the causal agent of Enteric Redmouth Disease (ERM) in fish. Annual

\section{ACKNOWLEDGEMENT}

We thank Cansu YILMAZ TERZi and Şükrü GÜNEŞ due to their help and support during the study period.

Reverse of Fish Diseases, 2, 105-125 DOI:10.1016/0959-8030(93)90031-6

Goda. A.M., El-Haroun, E.R. \& Kabir Chowdhury, M.A. (2007). Effect of totally or partially replacing fish meal by alternative protein sources on growth of African catfish Clarias gariepinus (Burchell. 1822) reared in concrete tanks. Aquaculture Research, 38, 279-287. DOI:10.1111/j.1365-2109.2007.01663.x

Gomes, E.F., Corraze. G. \& Kaushik, S. (1993). Effects of dietary incorporation of a co-extruded plant protein (rapeseed and peas) on growth, nutrient utilization and muscle fatty acid composition of rainbow trout. (Oncorhynchus mykiss). Aquaculture, 113, 339-353. DOI:10.1016/0044-8486(93)90404-M

Gregory, D., Wiens, R. \& Vallejo, L. (2010). Temporal and pathogenload dependent changes in rainbow trout (Oncorhynchus mykiss) immune response traits following challenge with biotype 2 Yersinia ruckeri. Fish and Shellfish Immunology, 29(1), 639-647. DOI:10.1016/j.fsi.2010.06.010

Hasipek, S. \& Aktaş, N. (1997). Türkiye'deki tavuk ürünlerinin insan beslenmesindeki önemi. Uluslararasi Tavukçuluk Fuarı ve Konferansı YUTAV 97, 14-17 Mayıs 1997, İstanbul, p 15-22.

Hopkins, K.D. (1992). Reporting fish growth: a review of the basics. Journal of the World Aquaculture Society, 23(3), 173-179. DOI: 10.1111/j.1749-7345.1992.tb00766.x

Hoşsu, B., Korkut, A.Y. \& Kop, A. (2012). Balık Besleme ve Yem Teknolojisi 1: (Balık Besleme Fizyolojisi ve Biyokimyası VII Baskı). Ege üniversitesi Su Ürünleri Fakültesi Yayınları, ISBN: 978-675-483-318-8, Yayın no: 50, Seri no:19, İzmir, p180.

Imsland, A.K., Foss, A., Gunnarsson, S., Berntssen, M., Fitz Gerald, R., Bonga, S.W. \& Stefansson, S.O. (2001). The interaction of temperature and salinity on growth and food conversion in juvenile turbot (Scophthalmus maximus). Aquaculture, 198, 353- 367 DOI:10.1016/S0044-8486(01)00507-5

Karabulut, H.A., Yandı, I. \& Aras, M. (2010). Effects of different feed and temperature conditions on growth, meat yield, survival rate, feed conversion ratio and condition factor in rainbow trout (Oncorhynchus mykiss) fingerlings. Journal of animal and Veterinary advances, 9(22), 2818-2823. DOI: 10.3923/javaa.2010.2818.2823

Kim, K.D., Jang, J.W., Kim, K.W., Lee, B.J., Hur, S.W. \& Han, H.S. (2018). Tuna by-product meal as a dietary protein source replacing fishmeal in juvenile Korean rockfish Sebastes schlegeli. Fisheries and Aquatic Sciences, 21(29), 1-8. DOI:10.1186/s41240-018-0107-y

Kroeckel, S., Harjes, A.G.E., Roth, I., Katz, H., Wuertz, S., Susenbeth, A. \& Schulz, C. (2012). When a turbot catches a fly: Evaluation of a prepupae meal of the Black Soldier Fly (Hermetia illucens) as fish meal substitute -Growth performance and chitin degradation in juvenile turbot (Psetta maxima). Aquaculture, 364-365, 345-352.

DOI:10.1016/j.aquaculture.2012.08.041

Leme, B.B., Sakomura, N., Viana, L., Melare, M.C., Oliveira, M.J.K. \& Mansano, C.F.M. (2019). Amino acid digestibility of feed Ingredients in cecectomized adult roosters. Brazilian Journal of Poultry Science, 21(2), 1-6. DOI:10.1590/1806-9061-2018-0924

Lock, E.J., Arsiwalla, T. \& Waagbø, R. (2014). Insect meal: a promising source of nutrients in the diet of Atlantic salmon (Salmo Salar). 1st International Conference Insects to Feed The World. 14-17 May 2014, p 67. Wageningen, The Netherlands, In Summary Report. Retrieved from: Abstract book Conference "Insects to Feed The World" (buglady.dk)

Lock, E.J., Arsiwalla, T. \& Waagbø, R. (2016). Insect larvae meal as an alternative source of nutrients in the diet of Atlantic salmon (Salmo salar) postsmolt. Aquaculture Nutrition, 22, 1202-1213. DOI:10.1111/anu.12343 
Luo, L., Xue, M., Wu, X., Caı, X., Cao, H. \& Lıang, Y. (2006). Partial or total replacement of fishmeal by solvent-extracted cottonseed meal in diets for juvenile rainbow trout (Oncorhynchus mykiss). Aquaculture Nutrition, 12, 418-424. DOI:10.1111/j.1365-2095.2006.00443.x

Millamena, O.M. (2002). Replacement of fish meal by animal by-product meals in a practical diet for grow-out culture of grouper Epinephelus coioides. Aquaculture, 204, 75-84. DOI:10.1016/S0044-8486(01)00629-9

Mills, D. (1989). You and Your Aquarium (2nd Edt). Colour Library Books Ltd. ISBN-10: 0862837332, 288 pages

Mohseni, M., Pourkazemi, M., Hosseni, M.R., Hassani, M.H.S. \& Bai, S.C. (2011). Effects of the dietary protein levels and the protein to energy ratio in sub-yearling Persian sturgeon, Acipenser persicus (Borodin). Aquaculture Research, 44(3), 378-387. DOI:10.1111/j.1365-2109.2011.03041.x

Morris, P.C., Gallimore, P., Handley, J., Hide, G., Haughton, P. \& Black, A.(2005). Fullfat soya for rainbow trout (Oncorhynchus mykiss) in freshwater: Effects on performance, composition and flesh fatty acid profile in absence of hind-gut enteritis. Aquaculture, 248(1-4), 147-161. DOI:10.1016/j.aquaculture.2005.04.021

Noga, E.J. (2010). Fish disease: Diagnosis and treatment. 2nd ed. USA: Wiley-Blackwell, ISBN: 978-0-813-80697-6, 536p.

NRC (National Research Council). (1993). Nutrient Requirements of Warmwater Fishes and Shellfishes (Revised edn). National Academy Press, Washington, p225.

Özogul, Y. (2000). The possibility of using crustacean waste products (cwp) on rainbow trout (Oncorhynchus mykiss) feeding. Turkish Journal of Biology, 24, 845-854.

Petterson A. 2010). Effects of replacing fish oil with vegetable oils in feed for Rainbow trout (Oncorhynchus mykiss) and arctic charr (Salvelinus alpinus). Doctoral Thesis, Acta Universitatis Agriculturae Sueciae.

Piper, R.G., McElwain, L.B., Orme, L.F., McCraden, J.P., Fowler, L.G. \& Leonard, J.R. (1982). Fish Hatchery Management. U.S. Fish and Wildlife Service, ISB: 0-913235-03-2, Washington D.C, U.S.A p61.

Prada, J.P., Cavalheiro, J.M.O., da Silva, J.A., Cavalheiro, T.B. \& da Silva, F.V.G. (2016). Amino acid profile and percent composition of meals and feeds used in shrimp farming. Gaia Scientia, 10(4), 347-360. DOI:10.21707/gs.v10.n04a28
Rahman, M.A., Bhadra, A., Begum, N. \& Hussain, M.G. (1997). Effects of some selective supplemental feeds on the survival and growth of catfish (Clarias batrachus lin.) fry. Bangladesh Journal of Fisheries Research, $1(2), 55-58$

Shiau, S.Y. \& Chen, S.Y. (1992). The influence of dietary energy levels with and without PCB induction on the growth of tilapia Oreochromis niloticus $\times$ Oreochromis aureus. Fish Physiology and Biochemistry, 10(4), 321 326. DOI: $10.1007 / B F 00004481$

Turan, H., Kaya, Y. \& Erkoyuncu, I. (2007). Protein and Lipid Content and Fatty Acid Composition of Anchovy Meal Produced in Turkey. The Turkish Journal of Veterinary and Animal Sciences, 31(2), 113-117.

Türk Gıda Kodeksi Yumurta Tebliği (2014, 20 Aralık). TC Resmi Gazete (Sayl: 29211). Retrieved from https://www.resmigazete.gov.tr/eskiler/2014/12/20141220-5.htm

Türkiye Yem Sanayicileri Birliği (2019). KarmaYem Sanayi Raporu. Retrieved from:

http://www.yem.org.tr/DosyaMerkezi/karma\%20yem\%20sanayii\%20rapo ru\%202019.pdf

Uslu, A.A., Ornekçi, G.N., Karakaya, G., Demir, T., Kuçukyılmaz, M., Celik, B.... Keleştemur, G.T. (2019). Gökkuşağı alabalığı (Oncorhynchus mykiss, Walbaum 1792) rasyonlarında balık ununa alternatif olarak yumurta unu kullanımının büyüme performansı, bazı kan parametre değerleri, vücut yağ asidi ve aminoasit kompozisyonu üzerine etkilerinin araştırıması. Tarımsal Araştırmalar ve Politikalar Genel Müdürlüğü Elazığ Su Ürünleri Araştırma Enstitüsü (Proje No. TAGEM/HAYSUD/2016/A11/P-01/3), Elazı̆̆.

Vendrell, D., Balcázar, J.L., Ruiz-Zarzuela, I., de Blas, I., Gironés, O. \& Múzquiz, J.L. (2006). Lactococcus garvieae in fish: a review. Comparative Immunology, Microbiology and Infectious Diseases, 29, 177-198. DOI: 10.1016/j.cimid.2006.06.003

Yem Muayene ve Analiz Metotları (1992, 21 Ocak). TC Resmi Gazete (Sayı: 21118). Retrieved from: https://www.resmigazete.gov.tr/arsiv/21118.pdf

Yeşilayer, N., Buhan, E., Kaymak, N. \& Akın, S. (2016). The effects of using Gammarus spp. meal added at different ratio to rainbow trout feeds as a source of protein replacement of fish meal on fish growth parameters. Gaziosmanpaşa Journal of Scientific Research, 12, 70-79. 